Review article

\title{
Türkiye'de 1998 ve 2020 Yılları Arasında Çocuk Haklarına Yönelik Yapılan Tez Çalışmalarının İncelenmesi
}

\section{Investigation of Studied Theses on Children Rights in Turkey Between}

\section{The 1998 and 2020 Years}

\author{
Aysun Aydin (10 * \\ Department of Physical Education and Sports Teaching, Institute Social Sciences, Ardahan University, Ardahan, Turkey
}

\begin{abstract}
Özet
Bu araştırmanın amacı Türkiye'de çocuk haklarına yönelik 1998-2020 yılları arasında yapılan yüksek lisans ve doktora tez çalışmalarının incelenmesidir. Araştırma verilerinin elde edilmesinde doküman inceleme tekniği kullanıımıştır. Bu çalışmada 25 tane yüksek lisans, 7 tane doktora tezi olmak üzere toplamda 32 tez çalışması incelenmiştir. Bu konudaki tezler; yayınlanma yılı, tez danışmanlarının unvanı, çalışmaların lisansüstü eğitim düzey türü, çalışmaların konu alan dağıımı, çalışmalarda tercih edilen araştırma yaklaşımı, çalışmalarda kullanılan veri toplama araçları açısından incelenmiştir. Araştırma bulguları, frekans ve yüzde şeklinde tablolar halinde ifade edilmiştir. Çalışma sonucu, çocuk hakları konusunda yürütülen lisansüstü tezlerin en çok 2019 yılında yapıldığı ve çocuk hakları konusunda yürütülen tezlerin çok büyük bir kısmının Dr. Öğr. Üyesi seviyesindeki öğretim üyeleri tarafından yürütüldüğü belirlenmiştir. Bu sonuca ek olarak çocuk hakları konusunda yürütülen yüksek lisans ve doktora tez çalışmalarının incelenmesin de büyük bir çoğunluğunun yüksek lisans düzeyinde olduğu belirlenmiştir. Yürütülen lisansüstü tezlerin konu alanı dağıımları incelendiğinde, tezlerin büyük bir kısmının çocuk hakları eğitimi, ihmal ve istismar açısından çocuk hakları ve medyada çocuk hakları konuları üzerine yoğunlaştığı ancak din boyutunda çocuk hakları, çocuk haklarına yönelik tutum çalışmaları ve ailede çocuk hakları konularının ise daha az çalışılan konular olduğu belirlenmiştir. Sonuç olarak kullanılan veri toplama araçları değişkeni açısından incelendiğinde yürütülen tezlerde en fazla anket en az ise gözlem tekniği kullanılarak verilerin toplandığı belirlenmiştir.
\end{abstract}

Anahtar Kelimeler: Çocuk, çocuk hakları, yüksek lisans, doktora.

\begin{abstract}
The purpose of this research is to investigate the master's and doctoral thesis carried out for children rights in Turkey between the 1998-2020 years. Document analysis technique was used to obtain research data. A total of 32 thesis studies, 25 of which were master's and 7 of which were doctoral thesis, were examined. Theses on this subject; The year of publication, the title of the thesis advisor, the type of graduate education of the studies, the subject area of the studies, the research approach in the studies, the data collection tools used in the studies were examined. Research findings are expressed in tables as frequency and percentage. The results of the study show that most of the postgraduate theses on children rights were made in 2019 and mostly by assistant professors. In addition to this result, it has been determined that most of the postgraduate theses on children rights are at the master's level. When the distribution of the subject areas of the postgraduate theses conducted is examined, most of the theses
\end{abstract}

\footnotetext{
* Corresponding author:

Aysun Aydın, Department of Physical Education and Sports Teaching, Institute Social Sciences, Ardahan University, Ardahan, Turkey. Email: aysunaydin36@gmail.com
} 
focus on child rights education, child rights in terms of neglect and abuse, and children rights in the media. In addition, it has been determined that children's rights in the dimension of religion, studies of attitude towards children's rights, children's rights in the family are less studied subjects. Finally, when the data collection tools used were examined, it was determined that the most questionnaire and the least observation technique were used in the conducted theses.

Keywords: Child, children rights, master, doctorate.

Received: 09 January $2021 \quad * \quad$ Accepted: 29 January $2021 \quad * \quad$ DOI: https://doi.org/10.29329/jcre.2020.287.5

\section{GíRIŞ}

Bir toplumun en kıymetli geleceği olan, geleceğe 1 şı tutacak olan değerleri, varlıkları çocuklardır. Çocuklar bir toplumun geleceğini şekillendirir, biçimlendirir ve topluma yön verirler. Çocuklara en üst düzeyde yaşam kalitesi sağlamaya, onları iyi bir insan olma özelliğiyle donatmaya ve onları iyi birer birey olmaya çalışan toplumlar ve devletler çocuklar için bir ülkenin geleceğidir (Ersoy, 2011a s.21-22). Genel olarak çocuk haklarını tanımlamamız gerekirse, çocuğun sosyal, ahlak, duygusal, zihinsel ve bedensel bakımdan saygınlık ve özgür bir biçimde yaşayan, sağlıklı bir şekilde büyümesi ve normal bir şekilde gelişebilmesi için hukuk kuralları ile çocukları koruyan çocukların gelecekleri için olan haklardır (Akyüz, Çolak, 2010). Aslında çocuk hakları insan haklarının altında yer alan haklar arasındadır ( Kurt, 2015). Bu yüzdendir ki çocuk hakları anayasal temel hakların ve insan haklarının 18 yaşını doldurmamış çocuklara tanınmasıyla ortaya çıkmış haklardır. İnsan Hakları sözleşmesinin çocuklar için geliştirilerek oluşturulmuş haklar olarak tanımlanmaktadır. Çocuk hakları sözleşme ilkeleri şunlardır; çocuklara sevgi, hoş görü, ayrımcılığın önlenmesi, çocuğun yararının gözetilmesi, adalet, eşitlik çocuğun kendisini ilgilendiren tüm süreçlere katılması ve ilgili konularda görüşlerinin alınması gibi sözleşme ilkeleri vardır. Çocuğun yaşamını sürdürme hakkı, yaşama hakkı, güvenli yaşama hakkı, ve kendini geliştirme hakkı çocuğun temel haklarıdır (Cılga, 2001). Tarihsel sürece bakılınca çocukların korunması gerekliliğinde esas ve yönteminde değişiklikler olmuştur. $\mathrm{Bu}$ değişiklikler sonucunda çocuk hakları konusunda birden fazla uluslararası sözleşmelerin imzalandığı ve böylelikle çocukların haklarının korunması yasalarla güvence altına alınıp korunmuştur. Bu imzalanan yasaların içinde en çok önem arz eden Çocuk Hakları Sözleşmesi'dir (Polat, 1997). Çocuk Hakları Sözleşmesine göre, çocukların ailesiyle ve çevresi içinde yaşaması, büyümesi, bakılması temeldir. Çocuklara aile bakımı içinde, annenin ve babanın çocuğuna yol gösterip, ona yardımcı olması yaşamında anne ve babanın sorumluluğu içinde öncelikli olarak belirtilmiştir. Çocuğun annesi ve babasından ayrılması durumunda çocuğun ekonomik, kültürel ve sosyal hakları hepsi Çocuk Hakları Sözleşmesi ile korunmuştur. Çocukların boş zamanlarının değerlendirilmesi ve kültürel etkinliklere katılımı olsun eğitimi olsun hepsini hak olarak ele alan bu sözleşmede, çocukların hepsinin eşit çağdaş eğitim ortamlarında aynı seviyede eğitim almalarını, çok yönlü düşünen, üreten, yeni ürünler çıkaran 
yaratıcılı̆̆ 1 gelişen birer bireyler olmasını hedeflemiştir (Dirican, 2018). Türkiye Cumhuriyeti Devleti Çocuk Hakları Sözleşmesini imzalayan bir devlet olarak çocuk haklarını herkesçe kabul görülen bir şekilde evrensel bir kriter çerçevesinde ele almayı kabul etmiştir (Washington, 2010). 1989 tarihinde Birleşmiş Milletler tarafından kabul edilmiş olan Çocuk Hakları Sözleşmesi dünya genelinde bakınca nerdeyse bütün ülkelerde yürürlüğe girmiştir. Çocuk Hakları Sözleşmesi, çocuğa toplumun bir bireyi, üyesi olduğunu hissettiren resmi bir sözleşmedir. Bu sözleşme her çocuğun yaşam standardını en iyi yapmayı isteyen, eğitim hakkını en iyi şekilde almasını isteyen çocuğun haklarını bildiren 54 madden oluşmaktadır. Bu 54 madde tüm çocukların bütün hakları eşit derecede önemli olduğunu ve her çocuğun aynı haklara sahip olduğunu vurgulamaktadır. Birleşmiş Milletler Çocuk Haklarına Dair Sözleşmede her bir madde ayrı bir hakkı ifade eden toplam dört bölümden oluşmaktadır. Bu haklar ise "katılım hakkı" , "hayatta kalma hakkı", "korunma hakkı" ve "gelişme hakkı" diye dört gruba ayrılmıştır (UNICEF, 2007:17). Çocukla ilgili sorumlu olan devlet, toplum, aile, okul vb. gibi birimlerin çocukların haklarının kusursuz bir şekilde yerine getirilmesinden ve bu tanınan çocuk haklara saygı gösterilmesinden dolayı sorumlulardır. Bu haklara bakacak olursak:

Hayatta Kalma Hakkı: Çocuğun var olması için ve yaşama hakkı için gereken temel ihtiyaçları vurgulayan haktır. Barınma, beslenme, iyi bir yaşam kalitesi ve sağlık hizmetlerin ulaşabilme gibi haklar yer almaktadir.

Korunma Hakkı: Çocukların ortaya çıkabilecek her hangi ihmal, sömürü ve istismardan korunmalarını gerektiren bir haktır. Küçük yaşta çalışan çocuklar için güvence, herhangi bir istismara uğramış veya maruz kalmış çocukların korunması sahip çıkılması, mülteci olarak ülkede bulunan çocuklar için yapılması gereken şeyler yapılıp özel olarak ilgilenilmesi.

Gelişme Hakkı: Çocukların gösterebilecekleri potansiyellerine ulaşabilmeleri için çocuğun neye ihtiyaç duyduğunu anlatan haktır. Bunlar; eğitim, bilgiye erişim, dinlenme, vicdan, kültürel faaliyetler, ve din özgürlügü gibi.( UNICEF, 2007:17).

Eğitim yuvası olan okullarda çocuk haklarının yaşatılması ve uygulanmasını sağlayan ana karakterler, okul yöneticileri ve öğretmenlerdir. Genel olarak bakıldığında yapılan eğitim bilimlerindeki çalışmalarda öğretmenlerin genel özelliklerinin, çocuklarda kişilik gelişiminde etkisi olduğu görülmektedir. Öğretmenin duygusal tepkileri, çeşitli alışkanlıkları, duygusal tepkileri çocukları etkilemektedir. Öğretmenlerin göstermiş olduğu davranışlar, eğitim sürecinin sonunda kazanılması gereken öğrencilerin yapacakları, gösterecekleri öğrenci davranışlarının belirleyicisidir. Öğretmenin öğrenciye kazandırılması istenen durumları önce kendisinin benimsemiş ve yaşamının ayrılmaz bir parçası haline getirmiş olması gerekir. (Varış, 1973, Akt: Şahin ve Uçuş,2012, s.27). Çocuk Hakları Sözleşmesi'nin maddelerinde geçen çocuk hakları eğitimi çocuk haklarının hayata geçirilmesinde önemli bir araçtır. Çocuk haklarını öğrenmesi onların bir birey olarak hangi haklara sahip olduklarını anlamaları ve öğrenmeleri anlamına gelir. Bu durumda öğretmenin okulda herhangi bir dersinde çocuk 
haklarını konu alacak şekilde ders işlemesinden kaynaklıdır. Öğrencilerin çocuk haklarını, okul ortamında, sınıf ortamında deneyimleyerek yaşaması da çocuk hakları sayesinde öğrenme olarak geçer. $\mathrm{Bu}$ sayede öğrenciler beceriler ve yeni tutum geliştirirler. Çocuk hakları için öğrenmede ise çocukların okulda, sınıfta ve herhangi bir toplulukta öğrendikleri bu temel haklarını kullanabilmeleri gerektiğini ve konuda da öğretmenler çocukları bilgilendirmelidir. Haklarını kullanabileceklerini, aktif olabileceklerini, öğrenme haklarının olduklarını bilmeleri gerekmektedir.(Gollob ve Krapf, 2007, Akt: Şahin ve Uçuş, 2012, s.27). Yapılacak olan bu çalışmada amaç çocuk haklarına yönelik yapılan çalışmaların incelenmesidir. Çocuk hakları ile ilgili farklı alanların nasıl araştırma yaptıklarını incelemektir.

\section{Çocuk Hakları Nedir?}

1989 tarihinde Birleşmiş Milletler tarafından, 0-18 yaş arasındaki bütün çocukların toplum, akraba, devlet, çevreden herhangi biri tarafından gelebilecek zararlardan korumak, zarar görmesini engellemek için oluşturulan toplamda 193 ülke tarafından kabul görülerek uygulanan temelinde çocukların gelişimsel, yaşamsal hakları, korunma, katılım, güvence haklarını koruma altına almayı hedefleyen resmi bir belgedir (Lansdown, 2005, Akt: Koran,2015). Çocuğun sahip olduğu temel haklarının ve özgürlüklerin çocuğa anlatılması, yapılması gereken durum haline gelmiştir. Böyle olunca çocuk hakları kavramı günümüzde ön plana çıkmaktadır. Çocuk hakları, çocuğun yaşadığı, bulunduğu toplumda aktif katılan ve çocuğun kimsenin baskısı etkisinde olmadan özgür bir birey olarak yetişmesinde çocuklar için önemli bir rol oynamaktadır. (Uçuş ve Şahin, 2012). Çocuk Hakları, 18 yaş altındakilerin haklarıdır. Çocukluk, insan hayatında değerli günlerin geçtiği anlamlı ve özel bir süreci kapsadığı için çocuklara ve gençlere ayrı haklar geliştirilmiştir. Bu dönem aralığı, çocukların büyüdüğü, geliştiği ve öğrendiği bir süreçtir. Ayrıca bu zamanda, çocukların korunması ve bakılması çevresindekilerinin yardımına ihtiyaç duydukları gibi bu dönemi eğlenceli özgür kendilerini rahatça ifade ederek geçirmeleri gereken dönemdir (UNICEF, 2007: 16). Çocuk hakları kavramına bir farklı tanımla bakacak olursak Avrupa Konseyi “çocukların insan hakları” olarak çocuğun ruhsal gelişimini, zihinsel gelişimini, fiziksel gelişimini daha tamamlamamış olmalarından kaynaklı olarak özel bakıma, korumaya gereksinim hissetmelerinin bir sonucu olarak uluslararası kuruluşların yardımıyla geliştirilmiş ve ulusal olarak da, resmi olarak da tanınmış temel çocuk haklarıdır (ASPB, 2013:4). İçinde bulunduğumuz zaman diliminde dünyada evrensel olarak barışın, özgürlügün, hoşgörünün, demokrasinin, güvenli yaşamın bir simgesi halini almış olan Çocuk Hakları ve İnsan Hakları gibi önemli olan iki kavramın geliştirilip ve daha nitelikli bir hali alabilmesi açısından büyük önem arz etmektedir. Çocuk Hakları İnsan Haklarının altında yer alan ve bu hakların doğal bir sonucu olarak oraya çıkan bu haklar gün geçtikçe önemini arttırarak günümüzde önemli bir yere sahiptir (Unutkan, 2008 Akt: Topsakal, 2012). 


\section{Dünyada Çocuk Hakları}

Dünyada çocuk olarak kabul edilen 0-18 yaş altı bireylerin korunması amaciyla birbirinden farklı çalışmalar yapılmıştır. 5. yüzyılda İspanya' da Çocuk İlkeleri başlığı altında çocuk haklarına yönelik ilk çalışmalar yapılmıştır. Ancak 18. Yüzyılda İsviçreli bilim adamı olan Pestalozzi çocukların karşılaştığı sorunları ve çocukların sahip olduğu hakları dile almıştır (Akyüz, 2000 Akt: Ezer ve Öteleş, 2020). Bu yüzdendir ki çocuk haklarının korunması için bir kurum ve kuruluşun olması gerektiğini savunan kişi ise J. Vune'dır (Kop ve Tuncel, 2010). İlk sistemli Çocuk Hakları çalışmasını ise Milletler Cemiyeti yapmıştır. Milletler Cemiyeti Cenevre Çocuk Hakları Bildirisini 1924 yılında kabul etmiştir. Kabul edilen bu bildiriye bakılınca bildiride çocukların yasal güvence altına alınması ve çocukların sahip olduğu haklara, çocukların güvenliğine değinilmiştir. Birleşmiş Milletler Genel Kurulu tarafindan 1989 tarihinde Çocuk Haklarına Dair Birleşmiş Milletler Sözleşmesi kabul edilmiştir. Yapılan bu sözleşmeyle cinsiyet, dil, din ve 1rk fark etmeksizin dünya üzerindeki tüm çocukların eşit haklara sahip olduğunu dilen alan sözleşmeyi imzalayan tüm devletlerce kabul edilmiştir (Akyüz, 2013). Hukuksal anlamda bakınca Çocuk Hakları ifadesi oldukça yeni bir kavram olup 21. Yüzyılda bazı sözleşmelerle düzenlenmeyle giderilmeye çalışılmıştır. Batı dünyasında yayılmaya başlayan Fransız İhtilali ve hümanistik düşünceler gibi bu tarz gelişmeler çocuklarda kendilerine yönelik özgü haklarının olduğunu düşüncesini uyandırmıştır (Akyüz, 2013:24).

\section{Türkiye'de Çocuk Hakları}

Türkiye adına 14.09.1990 tarihinde Çocuk Hakları Sözleşmesi imzalanmıştır. 058 sayılı kanunla 09.12.1994 tarihinde onaylanması uygun bulunmuştur ve 23.12.1994 tarihinde Bakanlar Kurulu tarafından 94/6423 sayıl1 kararla onaylanarak 22184 sayılı Resmi Gazetede 27.01.1995 tarihinde yayımlanarak yürürlüğe girmiştir (Akıllığlu, 1995).Türkiye Cumhuriyeti Devleti Çocuk Hakları Sözleşmesini imzalayarak çocuk haklarını evrensel ölçüt boyutunda ele almayı kabul görmüştür. Dolayısıyla Türkiye'de çocuk haklarına yönelik çalışmalar ve bu hakların öğretimine yönelik daha çok çalışma yapılmalıdır. Fakat bakınca bu konudaki çocuk hakları eğitim programlarının yok denecek kadar az olduğu görülmektedir(Washington, 2010). Türkiye'nin de kabul ettiği 1931 y1lında Cenevre Çocuk Hakları Bildirgesi Atatürk tarafından imzalanarak çocuğun gelişimi, eğitimi, çocuğun korunması ve çocuğun huzur ve barış içinde yetişmesini içeren bir bildiridir. Cenevre Çocuk Hakları Bildirgesi'nin ardından 1936 tarihinde Türkiye'nin de katılmış olduğu I. Balkan Kongresi toplanmış ve bu kongreyi, çalışma yaşı çocukların korunması ve sağlığı vb. konuların tartışıp konuşulduğu II. Balkan Kongresi takip etmiştir (Dinç, Biçkin ve Ayc1, 2004, Akt: Dirican, 2018). Uluslararası düzenlemelerin yapılması bir yana bir de her ülke ulusal olarak kendi ülkelerin de çocukların korunmasına yönelik bazı çalışmalar yapmaktadır. Türkiye'deki düzenlemelerin temelini çocukların korunmasını anayasada yer alan kanunlar oluşturmaktadır. 'Devlet, ailenin huzur ve refahı ile özellikle ananın ve çocukların korunması ve aile planlamasının öğretimi ile uygulanmasını sağlamak için gerekli tedbirleri alır, teşkilatı kurar ‘ 
maddesi anayasamızın 41. Maddesi olarak yer almaktadır. Ayrıca her çocuğun yeme içme, barınma, sağlık, bakım gibi alanlarda korunma ve bakımdan yararlanma, çocuğun yararında bir zarar olmadıkça, ebeveynleriyle doğrudan iletişim kurma ve hayatını sürdürme hakkına sahiptir. Çocukların şiddete ve çocuk istismarına karşı korumakta devletin görevidir ve devlet bu konuda koruyucu tedbirler alır. Böylece ulusal bir şekilde çocuk haklarına yönelik önlemler alınmaktadır (Karakaş ve Çevik, 2016).

\section{Çocukların Gözüyle Çocuk Hakları}

Çocuklara verilen bu hakların yalnızca yazıda kalmaması için bir çok kişiye görev düşmektedir. Bunlar; çocukların kendisini, ailesini, öğretmenlerini ve tüm toplumu ilgilendiren görevlerdir ve bu yüzden çocuk hakları konusunda farklılık oluşturmak toplumumuzda önemlidir (Dağ, Doğan, Sazak, Kaçar, Yılmaz, Doğan ve Arıca, 2015). Bu yüzden, çocukların çocuk haklarını algılama biçimleri, çocukların gözüyle çocuk hakları ve içerik olarak çocuk haklarının rolü hakkında yapılan araştırmalara ihtiyaç duyulmuştur (Limber, Kask, Heidmets, Kaufman ve Melton, 1999 Akt: Bayrak, Gök, Yörük ve Kaya 2019). Çocuk hakları farkındalığına yönelik yapmış olduğu çalışma incelendiğinde Şenol ve Akyol'e (2017) göre araştırmada çalışma grubunu, 48-60 aylık okul öncesi eğitim kurumuna devam eden toplam 20 çocuktan oluşmuştur. Yapmış oldukları araştırma sonucunda; çocukların çocuk haklarına yönelik bilgilerinin ve farkındalık düzeylerinin yapılan etkinlikler sonrasında arttığı belirlenmiştir. Bu çocuklar ilk önce hakları olarak oyun, beslenme ve uyku olduklarını söylemişlerdir ama uygulanan etkinlikler sonrası sağlik, korunma, yaşama hakkı, beslenme, oyun, durumlara katılma olarak bahsettikleri yapılan araştırmada görülmüştür. Bu yüzden çocukların gözünde çocuk hakları başlığından yola çıkarak yapılan çalışmalar incelenmiştir. Yazıcı ve Baydar (2015) tarafindan yapılan araştırma incelenince 60 ve 72 aylık çocukların, çocuk haklarına ilişkin algılarının çocuk resimleri ile incelenmesi amacıyla yapılan çalışmaya okul öncesi eğitim kurumunda devam etmekte olan toplamda 70 çocuk olacak şekilde 60 ve 72 aylık olacak şekilde çocuklar katılmıştır. Araştırmanın sonucu incelendiğinde yarısına yakını korunma hakkına 'sömürü, istismar ve ihmal' dedikleri, çocukların yarısından fazlası ise resimlerde ki gelişme hakkına 'eğitim, dinlenme, oyun, eğlence, düşünce ve vicdan özgürlüğü' dedikleri, yarısından fazlasının ise yaşama hakkına bakım, barınma ve beslenme' dedikleri, bir kısmı da katılım hakkına 'açıklama, karara katılma ve görüşlerini açıklama' dedikleri tespit edilmiştir. Ersoy (2011b) tarafından yapılan çalışmada çocukların saygı, kendini özgürce ifade etme, eşitlik gibi haklarını ön planda değil de daha çok eğitim, eğlenme ve oyun haklarını ön plana aldıkları görülmüştür. Hareket, Çağlayan ve Dündar (2016) tarafında yapılan araştırmada da çocukların hemen hemen büyük çoğunluğu oyun, korunma ve eğitim haklarından bahsettikleri belirlenmiştir. Yapılan çalışma sonuçlarına göre bu haklar genel olarak gelişimsel haklar kapsamında değerlendirildiği için çocukların daha çok haklarını daha gelişimsel haklar kapsamında bildikleri söylenebilir. 


\section{YÖNTEM}

\section{Araştırma Amacı}

Yapılan bu araştırmanın amacı Türkiye'de çocuk hakları konusunda 1998-2020 yılları arasında yapılmış olan lisansüstü tez çalışmalarının çeşitli açılardan incelemektir.

\section{Araştırma Modeli}

Bu çalışmanın yürütülmesinde doküman inceleme yöntemi kullanılmıştır.. Doküman incelemesi; nitel bir veri toplama yöntemidir ve yayımlanmış kitap, dergi gibi yazılı materyalleri analiz etmek için kullanılır (Karasar, 2008). Çalışmada (YÖK) Ulusal Tez Merkezi sitesinden tezler indirilip genel bir çalışma yapılmıştır. 25 tanesi yüksek lisans, 7 tanesi de doktora tez çalışması olmak üzere toplamda 32 tez çalışması incelenmiştir.

\section{Bulgular}

Yapılan bu araştırmanın bu bölümünde, çocuk hakları konusun da gerçekleştirilen doktora ve yüksek lisans tez çalışmalarının, farklı kategoriler açısından yapılan literatür incelemesi sonuçlarına ve elde edilen bulgulara yer verilmiştir. Bu konudaki tezler; yayınlanma yılı, tez danışmanlarının unvanı, çalışmaların lisansüstü eğitim düzey türü, çalışmaların konu ve alan dağılımı, çalışmalarda tercih edilen araştırma yaklaşımı, çalışmalarda kullanılan veri toplama araçları açısından incelenmiştir. Araştırma bulguları, frekans ve yüzdelik sonuçlar şeklinde tablolar haline getirilerek tablo şeklinde yorumlamaları gerçekleştirilmiştir.

Tablo 1.Tez Çalışmalarının Gerçekleştirildiği Yıllara Göre Dağılımları

\begin{tabular}{|c|c|c|}
\hline YIL & Frekans (f) & Yüzde (\%) \\
\hline 1998 & 1 & 3,1 \\
\hline 2004 & 1 & 3,1 \\
\hline 2009 & 2 & 6,2 \\
\hline 2010 & 1 & 3,1 \\
\hline 2011 & 1 & 3,1 \\
\hline 2013 & 3 & 9,3 \\
\hline 2014 & 1 & 3,1 \\
\hline 2016 & 1 & 3,1 \\
\hline 2017 & 2 & 6,2 \\
\hline 2018 & 5 & 15,6 \\
\hline 2019 & 12 & 37,5 \\
\hline 2020 & 2 & 6,2 \\
\hline Toplam & 32 & 100 \\
\hline
\end{tabular}

Tablo 1'de, yapılmış olan tez çalışmalarının yayın yıllarına ilişkin bilgilere yer verilmiştir. En çok çalışma yapılan üç seneye bakacak olursak Tablo 1'e göre 2019 yılının yapılan konuyla ilgili en fazla 
tez çalışmasının yayınlandığı $(\% 37,5)$ yıl olduğu görülmektedir. 2018 y1lında yayınlanan tezlerin ise $(\% 15,6)$ Türkiye'de Çocuk Hakları Konusunda Yapılan Lisansüstü Tezlerin Literatür İncelenmesi ile ilgili konuda en çok tez çalışmasının yayınlandığı ikinci yıl olduğu, 2013 yılında yayınlanan tezlerin $(\% 9,3)$ en çok tez çalışmasının yayınlandığı üçüncü sıradaki yıllar oldukları tespit edilmiştir.

Tablo 2. Tez Çalışmalarının Danışman Unvanlarına Göre Dağılımları

\begin{tabular}{lcc}
\hline Danışman Unvanı & Frekans (f) & Yüzde (\%) \\
\hline Profesör Doktor & 8 & 25 \\
Doçent Doktor & 6 & 18,7 \\
Yardımcı Doçent Doktor & 18 & 56,2 \\
Toplam & 32 & 100 \\
\hline
\end{tabular}

Tablo 2'de, gerçekleştirilen tez çalışmalarının, danışman unvanlarına göre dağılımına yer verilmiştir. Yapılan bu tez çalışmalarına danışmanlık eden hocaların çoğunlukla \%56,2) yardımcı doçent doktor, ikinci olarak ise \% 25 profesör ve son olarak ise \%18,7 doçent unvanına sahip kişiler oldukları görülmüştür.

Tablo 3. Tez Çalışmalarının Lisansüstü Eğitim Düzeyi Türüne Göre Dağılımları

\begin{tabular}{lcc}
\hline Tez Türü & Frekans (f) & Yüzde (\%) \\
\hline Yüksek Lisans & 25 & 78,1 \\
Doktor & 7 & 21,8 \\
Toplam & 32 & 100 \\
\hline
\end{tabular}

Tablo 3'de, gerçekleştirilen tez çalışmalarının lisansüstü eğitim düzey türüne ilişkin bilgilere yer verilmiştir. Tablo incelendiğinde, tezlerin \% 78,1'i yüksek lisans ve \% 21,8'i ise doktora tezi olarak incelediği belirlenmiştir.

Tablo 4. Tez Çalışmalarının Konu ve Alan Dağılımları

\begin{tabular}{lcc}
\hline Makalelerin Konu Alanı & Frekans (f) & Yüzde (\%) \\
\hline Çocuk Hakları Eğitimi & 8 & 25 \\
Çocuk Suçluluğu Yönünden Çocuk Hakları & 3 & 9,3 \\
Medyada Çocuk Hakları & 4 & 12,5 \\
Çocuk Haklarına Yönelik Tutum Çalışmaları & 2 & 6,2 \\
Çocuk Haklarına Yönelik Görüşv ve Algıı Çalışması & 3 & 9,3 \\
Çalışan Çocuklar Bakımından Çocuk Hakları & 3 & 9,3 \\
Din Boyutunda Çocuk Hakları & 1 & 3,1 \\
İhmal ve İstismar Açısından Çocuk Hakları & 7 & 21,8 \\
Ailede Çocuk Hakları & 1 & 3,1 \\
Toplam & 32 & 100 \\
\hline
\end{tabular}


Tablo 4 incelendiğinde, sırasıyla tez çalışmalarının en çok ilk üç sırada olan konulara bakınca; çocuk hakları eğitimi $(\% 25)$ birinci, ihmal ve istismar açısından çocuk hakları $(\% 21,8)$ ikinci, medyada çocuk hakları $(\% 12,5)$ üçüncü sırada konu alanlarının gerçekleştirildiği belirlenmiştir. Araştırmada ayrıca, çocuk haklarına yönelik tutum çalışmalarının, din boyutunda çocuk hakları ve ailede çocuk hakları konu alanlarına ilişkin çalışmaların oldukça sınırlı olduğu görülmüştür.

Tablo 5. Tez Çalışmalarında Tercih Edilen Araştırma Yaklaşımı Dağılımı

\begin{tabular}{lcc}
\hline Araştırma Yaklaşımı & Frekans (f) & Yüzde (\%) \\
\hline Nitel & 17 & 53,1 \\
Nicel & 5 & 15,6 \\
Karma & 6 & 18,7 \\
Derleme & 4 & 12,5 \\
Toplam & 32 & 100 \\
\hline
\end{tabular}

Tablo 5'de, tez çalışmalarının araştırma yaklaşımına ilişskin bulgulara yer verilmiştir. Yer verilen bu bulgular incelendiğinde, tez çalışmalarının daha çok nitel yaklaşıma sahip olduğu $(\% 53,1)$ tespit edilmiştir. Ayrıca araştırmada, tezlerin $(\% 15,6)$ nicel yaklaşıma sahip olduğu, $(\% 18,7)$ karma araştırma yaklaşıma sahip olduğu, $(\% 12,5)$ alan-yazın derleme yaklaşıma sahip olduğu görülmüştür. Tez çalışmalarında kullanılan veri toplama araçlarının detaylı açıklamasına, Tablo 6'da yer verilmiştir.

Tablo 6. Tez Çalışmalarında Kullanılan Veri Toplama Araçlarının Dağılımları

\begin{tabular}{lll}
\hline Veri Toplama Aracı & Frekans (f) & Yüzde (\%) \\
\hline Anket & 15 & 33,3 \\
Bilgi Formu & 8 & 17,7 \\
Görüşme & 7 & 15,5 \\
Gözlem & 2 & 4,4 \\
Doküman & 8 & 17,7 \\
Diğer & 5 & 11,1 \\
Toplam & 45 & 100 \\
\hline
\end{tabular}

Tablo 6 incelendiğinde, tezlerin çoğunda; anketlerin (\%33.3) veri toplama aracı olarak çalışmalarda kullanıldığı görülmektedir. Yapılan araştırmada anketten sonra en çok tercih edilen veri toplama araçlarının,(17,7) bilgi formu ve doküman inceleme olduğu belirlenmiştir.

\section{Tartışma ve Sonuç}

Yapılan bu araştırma ile çocuk haklarına yönelik gerçekleştirilmiş lisansüstü tez çalışmalarının tematik olarak incelenmesi amaçlanmıştır. Bu amaç doğrultusunda 32 lisansüstü tez çalışması farklı açılardan incelenmiştir. Gerçekleştirilen, tez çalışmalarında tercih edilen araştırma yaklaşım dağılım bulguları incelendiğinde; çocuk hakları konusunda en fazla nitel çalışmaların gerçekleştirildiği, tez 
çalışmalarının konularının genellikle çocuk hakları eğitimi, ihmal ve istismar açısından çocuk hakları konuları üzerinde yoğunlaştığı görülmüştür. Tez çalışmalarında, anketlerin, bilgi formlarının ve doküman incelemenin en çok tercih edilen veri toplama araçları olduğu görülmüştür. Çocuk hakları konusunda yürütülen lisansüstü tezlerin en fazla 2019 yılında yapıldığı bu da son yıllarda çocuk hakları konusunun daha çok gündemde olduğunu, gelişen dünyanın çocuğa daha çok önem vermeye başladığını, toplumumuz da çocuğun öneminin daha fazla arttığını bu yüzden günümüzde daha çok incelemeler yapıldığı düşünülmektedir. Buna ek olarak çocuk hakları konusunda yürütülen tezlerin büyük bir kısmının Dr. Öğr. Üyesi eviyesindeki öğretim üyeleri tarafından yürütüldüğü ve çocuk hakları konusunda yürütülen lisansüstü tezlerin büyük bir çoğunluğunun ise yüksek lisans düzeyinde olduğu belirlenmiştir. Yürütülen lisansüstü tezlerin konu alanı dağılımları incelendiğinde tezlerin büyük bir kısmının çocuk hakları eğitimi, ihmal ve istismar açısında çocuk hakları ve medyada çocuk hakları konuları üzerine yoğunlaştığı ancak din boyutunda çocuk hakları, çocuk haklarına yönelik tutum çalışmaları ve ailede çocuk hakları konularının ise daha az çalışılan konular olduğu belirlenmiştir. İncelenen tezlerin tercih edilen araştırma yaklaşım değişkenine bakılınca en çok nitel araştırma yaklaşımı kullanıldığı görülmüştür. Son olarak ise kullanılan veri toplama araçları değişkeni açısından incelendiğinde yürütülen tezlerde en fazla anket en az ise gözlem tekniği kullanılarak veri toplandığı belirlenmiştir.

\section{Öneriler}

$\mathrm{Bu}$ araştırmanın ortaya koyduğu sonuçlara dayanarak şunlar önerilebilir:

- Dr. Öğr. Üyesi dışındaki diğer öğretim üyelerinin de çocuk hakları konularına yoğunlaşması önerilmektedir.

- Çocuk hakları konusunda medya destekli faaliyetler yürütülmelidir.

- Çocuk hakları konusunda doktora eğitim düzeyinde de çalışmalar yapılmalıdır.

- Çocuk hakları konusunda yürütülen lisansüstü tezlerde daha derinlemesine sonuçların elde edilmesine olanak sağlayan alternatif yöntem ve teknikler kullanılmalıdır.

- Çocuk hakları konusunda yürütülmesi planlanan lisansüstü tez çalışmalarında çocuk haklarının dini boyutu ve ailede çocuk hakları konularına değinilmesi önerilmektedir.

\section{KAYNAKÇA}

Akıllığlu, T. (1995). Çocuk Haklarına Dair Sözleşme. İnsan Hakları Merkezi Yayınları, No:13, Ankara 1995

ASPB, Aile Ve Sosyal Politikalar Bakanlığı, (2013). Ulusal Çocuk Hakları Strateji Belgesi Ve Eylem Planı 2013-2017(2013). Ankara 
Akyüz, E. (2000). Ulusal Ve Uluslararası Hukukta Çocuğun Haklarının Ve Güvenliğinin Korunması. Ankara: Milli Eğitim Basımevi.

Akyüz, E. (2013). Çocuk Hukuku: Çocukların Hakları Ve Korunması Ankara: Pegem Akdemi.

Bayrak, H. Gök, H. Yörük, E. Kaya, E. (2019), Okul Öncesi Dönemindeki Çocukların Gözünden Çocuk Hakları 1 Children's Rights İn The Eyes Of Preschool Children, Uluslararası Erken Çocukluk Eğitimi Çalışmaları Dergisi International Journal of Early Childhood Education Studies Eylül 2019 Cilt: 4 Sayı: 2

C1lga, İ. (2001). Demokrasi İnsan Hakları Kültürü Ve Çocuk Hakları. Milli Eğitim Dergisi, 151. 3. 69-73.

Dağ, H. Doğan, M. Sazak, S. Kaçar, A. Yılmaz, B. Doğan A. ve Arıca, (2015), Çocuk Haklarına Güncel Yaklaşım, Çukurova Medical Journal 2015 40(1):1-5.

Dirican,R. ( 2018). Tarihi Süreçte Çocukluk Ve Çocuk Hakları, Çocuk Ve Gelişim Dergisi (ÇG-D) JournalOf Child AndDevelopment (J-CAD) Cilt 2 (2018) Sayı 2 51-62

Doğan, G. (2017). Çocuk Hakları Eğitiminde Uzman Sınıf Öğretmenlerin

Perspektifinden Etkili Çocuk Hakları Eğitimi: Anlayışlar Ve Uygulamalar

Ersoy, A. F. (2011a). İlköğretim Öğrencilerinin Çocuk Haklarına İlişkin Algıları. İlköğretim Online, 10(1), 20-39

Ersoy, A.F. (2011b) "Çocuk Haklarına İlişkin Temel Kavramlar Ve Çocuk Hakları Sözleşmesi Okulöncesinde Demokrasi Eğitimi Ve Çocuk Hakları”, Editör: Handan Deveci, Şefik Yaşar, Kıymet Selvi, Handan Deveci, Turan Akman Erkılıç, Meral Güven, Anadolu Üniversitesi Yayını No: 1821 Açıköğretim Fakültesi Yayını No: 944, Eskişehir: 21-46.

Ezer, F, Öteleş, Ü.U, (2020), Çocuk Haklarına Yönelik Tutumun Belirlenmesi: Nicel Bir Araştırma

Karakaş, B. Çevik, Ö. (2016), Çocuk Refahı: Çocuk Hakları Perspektifinden Bir Değerlendirme.

Karasar, N. (2008). Bilimsel araştırma yöntemi: kavramlar-ilkeler-teknikler. Nobel Yayın Dağıtım.

Kop, Y. Tuncel, G. (2010). Sosyal Bilgiler Öğretmelerinin Çocuk Haklarını Algılamaları, Journal Of Theory\&Practice İn Education (JTPE), 6(1), 106-124.

Koran, N (2015). Öğretmenlere Yönelik Çocuk Hakları Ve Hak İhlalleri Eğitiminin Değerlendirilmesi Üzerine Nitel Bir Çalışma, Uluslararası Katılımlı Iıı. Çocuk Gelişimi Ve Eğitimi Kongresi “Erken Müdahale

Kurt, S. L. (2015) Çocuk Haklarına İlişkin Temel Uluslararası Belgeler Ve Türkiye Uygulaması

Polat, O. (1997). Çocuk ve Çocuk Hakları. İstanbul: Analiz Yayınları

Şahin, A. Uçuş Ş. (2012). Çocuk Hakları Sözleşmesi’ne Yönelik Öğretmenlerin Ve Okul Yöneticilerinin Görüşleri, Adnan Menderes Üniversitesi Eğitim Fakültesi Eğitim Bilimleri Dergisi, Haziran 2012, 3 (1), 25-41

Şenol, F. B. Ve Akyol, T. (2017). Okul Öncesi Dönem Çocuklarının Çocuk Haklarına Yönelik Farkındalıklarını Geliştirmeye Yönelik Bir Uygulama Örneği (Pilot Çalışma). Ö. Pınarcık Ve M. Özözen Danacı (Ed.), Uluslararası Çocuk Hakları Kongresi Tam Metin Kitabı (S. 299-312) İçinde. Ankara: Eğiten Kitap. ISBN:978-975-2435-91-9. 
Topsakal, C, Ayyürek O, (2012)Sınıf Öğretmenlerinin Görüşlerine Göre Öğrencilerin Çocuk Haklarını Kullanmaları, Eğitim Bilimleri Dergisi, Aralık 2012, Cilt: 3, Sayı: 2, 37-53

Uçuş, Ş.(2013). Çocuk Hakları Eğitimi Programının Hazırlanması Ve Değerlendirilmesi

UNICEF, (2007). Çocuk Hakları Ve Gazetecilik Uygulamaları, Hak Temelli Perspektif. Dublin: Teknoloji Enstitüsü

Yazıcı, E. Ve Baydar, I. Y. (2015). 60-72 Aylık Çocukların Çocuk Haklarına İlişkin Algılarının Resim Yoluyla İncelenmesi. Aced Uluslararası Aile Çocuk Ve Eğitim Dergisi, 7, 1-19.

\section{İncelenen Tezler}

Aksu, A.B.(2004), Medya, Çocuk Ve Din Eğitimi, Uludağ Üniversitesi, Sosyal Bilimler Enstitüsü, Felsefe ve Din Bilimleri Ana Bilim Dalı, Din Eğitimi Bilim Dalı, Doktora Tezi

Ateşoğlu, N.(2018), İlkokul Çocuklarına Yönelik İhmal Ve İstismarı Önleme: Bir Ana Baba Eğitim Programının Değerlendirilmesi, Ankara Üniversitesi, Eğitim Bilimleri Enstitüsü Eğitimde Psikolojik Hizmetler Anabilim Dalı, Eğitim Psikolojisi Programı, Yüksek Lisans Tezi

Barlık, H. (2018), Okul Öncesi Öğretmenlerinin Çocuk İhmal Ve İstismarı Hakkında Görüş Ve Farkındalık Düzeylerinin Araştırılması,Çağ Üniversitesi Sosyal Bilimler Enstitüsü Psikoloji Anabilim Dalı, Yüksek Lisans Tezi

Can, V. (2016), Öğretmen Adaylarının Çocuk İhmal Ve İstismarına YönelikBilgi Ve Farkındalık Düzeylerinin Değerlendirilmesi, Dicle Üniversitesi, Eğitim Bilimleri Enstitüsü, Eğitim Bilimleri Anabilim Dalı, Eğitim Programları Ve Öğretim Bilim Dalı, Yüksek Lisans Tezi

Çarıkçı, S. (2019), Çocuk Hakları Eğitimi Programı'nın İlkokul 4. Sınıf Öğrencilerinin Çocuk Hakları Tutum Ve Farkındalıklarına Etkisi Marmara Üniversitesi, Eğitim Bilimleri Enstitüsü, İlköğretim Anabilim Dalı, Sınıf Öğretmenliği Bilim Dalı, Doktora Tezi

Dağlığlu, A. (2009), Çalışan Çocukların Yaşam Koşulları Ve Örgün Eğitim Yoluyla Topluma Kazandırılması, Ankara Üniversitesi Eğitim Bilimleri Enstitüsü Eğitimin Kültürel Temelleri Anabilim Dalı Yaşam Boyu Öğrenme Bilim Dalı (Halk Eğitimi Programı), Yüksek Lisans

Dikmen, A. (1998), Çocuk Haklarına Dair Sözleşme Çerçevesinde İstanbul'da Çalışma Çocuklar Üzerine Değerlendirme, Mimar Sinan Üniversitesi Sosyal Bilimler Enstitüsü Genel Sosyoloji Ve Metodoloji Program1, Doktora Tezi

Dinç, A. (2013). Çocuk Suçluluğunda Ailenin Rol, Kırıkkale Üniversitesi, Sosyal Bilimler Enstitüsü, Sosyoloji Anabilim Dalı, Yüksek Lisans Tezi

Doğan, A. (2019), Okul Öncesi Öğretmenlerinin Çocuk İhmal Ve İstismarı Belirti Ve Riskleri Konusunda Bilgi Düzeylerinin İncelenmesi, İstanbul Okan Üniversitesi Sağlık Bilimleri Enstitüsü, Yüksek Lisan Tezi

Doğan, G.(2017), Çocuk Hakları Eğitiminde Uzman Sınıf Öğretmenlerin Perspektifinden Etkili Çocuk Hakları Eğitimi: Anlayışlar Ve Uygulamalar,Gaziantep Üniversitesi, Eğitim Bilimleri Enstitüsü, Temel Eğitim Ana Bilim Dalı, Yüksek Lisans Tezi

Durgut, A. (2014), 2005 Sosyal Bilgiler Dersi Öğretim Programlarının Çocuk Hakları Açısından İncelenmesi, Dumlupınar Üniversitesi, Eğitim Bilimler Enstitüsü, İlköğretim Anabilim Dalı, Sosyal Bilgiler Eğitimi Bilim Dalı, Yüksek Lisans Tezi 
Ergen, M.K. (2017), Okul Müdürlerinin Bayrak Törenlerinde Yaptıkları Konuşmaların Çocuk Hakları Açısından İncelenmesi, İstanbul Sabahattin Zaim Üniversitesi Marmara Üniversitesi Eğitim Yönetimi Ve Denetimi ortak Yüksek Lisans Programı, Yüksek Lisans Tezi

Geliş A.(2020), Bm Çocuk Hakları Sözleşmesinde Çocuğun İnanç Özgürlüğü, Ankara Üniversitesi, Sosyal Bilimler Enstitüsü, İnsan Hakları Anabilim Dalı, Yüksek Lisans Tezi

Gençer, R. (2018), Medya Çocuk İlişkisi Bağlamında Mevcut Duruma İlişkin Çalışma Sonuçlarının İncelenmesi, Sakarya Üniversitesi Eğitim Bilimleri Enstitüsü

Türkçe Ve Sosyal Bilimler Eğitimi Anabilim Dalı, Sosyal Bilgiler Eğitimi Bilim Dalı, Yüksek Lisans Tezi

Gülbahar, O. (2019), Okul Yöneticileri Ve Velilerin Çocuk Hakları Sözleşmesi’nin

Eğitim Hakk1 İle İlgili Hükümlerinin Uygulanmasına İlişkin Görüşleri, Ankara Üniversitesi Eğitim Bilimleri Enstitüsü Eğitim Yönetimi Ve Politikası Anabilim Dalı Eğitim Yönetimi Ve Teftişi Programı, Yüksek Lisans Tezi

Güngor, A. (2019), Sosyal Medyada Çocuk Hakları İhlali Ve İstismarı: Instagram Anneleri, Marmara Üniversitesi, Sosyal Bilimler Enstitüsü, Gazetecilik Anabilim Dal, Genel Gazetecilik Bilim Dalı, Yüksek Lisan Tezi

Hamarat, H.Y (2019). Kentleşme Ve Çocuk Suçluluğu, Karadeniz Teknik Üniversitesi, Sosyal Bilimler Enstitüsü, Kamu Yönetimi Bölümü Anabilim Dalı, Kamu Yönetimi Programı, Yüksek Lisans Tezi

Hançer, G. (2019), Çocuk Hakları Ve Çocuk İstismarı Konusunda Sosyal BilgilerÖğretmen Adaylarının Görüşleri, Kastamonu Üniversitesi, Sosyal Bilimler Enstitüsü

Türkçe Ve Sosyal Bilimler Eğitimi Ana Bilim Dalı, Yüksek Lisans Tezi

İnan, T. (2013), Medya Okuryazarlığı Sürecinde Medya, Çocuk Ve Ebeveyn İlişkisi: Ortaokul Öğrencilerinin Ve Ebeveynlerinin Televizyon Ve İnternet Kullanımlarına İlişkin, Dumlupınar Üniversitesi Eğitim Bilimleri Enstitüsü, İlköğretim Anabilim Dalı Tutum Ve Davranışlarının İncelenmesi, Doktora Tezi

İşler, M. (2019), Öğretmen Adaylarının Çocuk Haklarına Yönelik Görüşlerinin Bazı Değişkenler Açısından İncelenmesi, Van Yüzüncü Yıl Üniversitesi Eğitim Bilimleri Enstitüsü

Eğitim Programı Ve Öğretimi Anabilim Dalı Eğitim Programı Ve Öğretimi Bilim Dal, Yüksek Lisans Tezi

Kalender, B.(2018), Hayat Bilgisi Dersi Öğretim Programlarının Çocuk Hakları Sözleşmesinin Eğitim Hedefleri Maddesi Açısından İncelenmesi: Tarihsel Bir Analiz,

Gaziantep Üniversitesi, Eğitim Bilimleri Enstitüsü, Temel Eğitim Anabilim Dalı, Yüksek Lisans Tezi

Kara, S. B. (2011), Sokakta Çalışan Çocukların Eğitim İhtiyaçları Ve Buna Yönelik Okul Yönetimlerinin Gerçekleştirdiği Uygulamalar, Gazi Üniversitesi Eğitim Bilimleri Enstitüsü Eğitim Bilimleri Ana Bilim Dalı Eğitim Yönetimi Ve Denetim Bilim Dalı, Doktora Tezi

Karaçor, Ö. (2019), Rehber Öğretmenlerin Çocuk İhmal Ve İstismarına Yönelik Farkındalık Düzeylerinin İncelenmesi (Tarsus İlçesi Örneği),Selçuk Üniversitesi, Sosyal Bilimler Enstitüsü, Aile Danışmanlığ Ve Eğitimi Anabilim Dalı, Aile Danışmanlığı Ve Eğitimi Bilim Dalı, Yüksek Lisan Tezi

Kesayak, Y.(2018), Ailede Çocuk Haklarının Uygulanma Düzeyine İlişkin Ebeveyn Görüşleri, Kastamonu Üniversitesi Sosyal Bilimler Enstitüsü İlköğretim Ana Bilim Dalı Sınıf Öğretmenliği Bilim Dalı, Yüksek Lisans Tezi 
Konuk, G. (2019). Avrupa Birliği’ne Uyum Sürecinde Türkiye'de Çocuk Hakları Ve Çocuk Suçluluğu, Marmara Üniversitesi, Avrupa Araştırmaları Enstitüsü, Avrupa Siyaseti Ve Uluslararası İlişkiler Anabilim Dalı, Yüksek Lisans Tezi

Platin, G.(2019). Okul Öncesi Öğretmen Adaylarının Çocuk Haklarına İlişkin Tutumlarının İncelenmesi, Trakya Üniversitesi, Sosyal Bilimler Enstitüsü, Temel Eğitim Anabilim Dalı, Okul Öncesi Öğretmenliği Bilim Dalı, Yüksek Lisans Tezi

Püsküllü, F. (2020). Rehberlik Psikolojik Danışmanlık Öğrencilerinin Çocuk Haklarına Dair Farkındalıklarının İncelenmesi, Maltepe Üniversitesi, Eğitim Bilimleri Anabilim Dalı Rehberlik Psikolojik Danışmanlık, Yüksek Lisans Tezi

Topçu, B. (2019), Yaratıı Drama Temelli Çocuk Hakları Eğitimi Programının Geliştirilmesi Ve Uygulanması, Gaziantep Üniversitesi, Eğitim Bilimleri Enstitüsü, Temel Eğitim Ana Bilim Dalı, Yüksek Lisans Tezi

Toydemir, A. (2019), Özel Eğitim Kurumlarında Çalışan Öğretmenlerin Çocuk İhmal Ve İstismarına İlişkin Bilgi Ve Farkındalık Düzeylerinin İncelenmesi, Necmettin Erbakan Üniversitesi, Eğitim Bilimleri Enstitüsü, Özel Eğitim Ana Bilim Dalı, Özel Eğitim Bilim Dalı, Yüksek Lisans Tez

Uçuş, Ş. (2013), Çocuk Hakları Eğitimi Programının Hazırlanması Ve Değerlendirilmesi, Hacetepe Üniversitesi Eğitim Bilimleri Enstitüsü, İlköğretim Anabilim Dalı, Doktora Tezi

Yurtsever, M. (2009), Ebeveyn Çocuk Hakları Tutum Ölçeğinin Geliştirilmesi Ve Anne Babaların Çocuk Haklarına Yönelik Tutumlarının Farklı Değişkenler Açısından İncelenmesi, Marmara Üniversitesi, Eğitim Bilimleri Enstitüsü, İlköğretim Ana Bilim Dalı, Okul Öncesi Öğretmenliği Bilim Dalı, Doktora Tezi

Washington, F. (2010). 5-6 Yaş Grubu Çocuklarına Uygulanan Aile Katılımlı Çocuk Hakları Eğitimi Programının Etkililiğinin İncelenmesi. Yayınlanmamış Yüksek Lisans Tezi, Marmara Üniversitesi Eğitim Bilimleri Enstitüsü, İlköğretim Ana Bilim Dalı, Okul Öncesi Öğretmenliği Bilim Dalı, Yüksek Lisans Tezi 